\title{
Supratentorial tanycytic ependymoma An uncommon fibrillary ependymoma variant
}

\author{
Fabiano Reis', Ricardo Schwingel ${ }^{4}$, Francisco Carlos de Morais ${ }^{3}$, Luciano de Souza Queiroz ${ }^{2}$
}

A 6-year-old boy with focal seizures and headache. Diagnostic imaging demonstrated a right subcortical parietooccipital heterogeous expansive lesion, with growth into the adjacent ventricular system (Fig 1). Histological analysis led to the diagnosis of tanycytic ependymoma, as tumor cells have features resembling tanycytes (Fig 2).

More than half of these tumors occur in the spinal cord. Supratentorial location is very rare, and may arise, as in this case, around the ventricle or from subcortical white matter ${ }^{1-3}$.
ACKNOWLEDGEMENT - Anatomical specimen kindly referred by

Dr. José Ribeiro de Menezes Netto, Campinas, SP.

\section{REFERENCES}

1. Ito T, Ozaki Y, Nakamura H, Tanaka S, Nagashima K. A case of tanycytic ependymoma arising from the cerebral hemisphere. Brain Tumor Pathol 2006;23:91-95.

2. Richards AL, Rosenfeld JV, Gonzales MF, Ashley D, Mc Lean C. Supratentorial tanycytic ependymoma. J Clin Neurosci 2004;11:928-930.

3. Takahashi H. Tanycytic ependymoma. Clin Neurosci 2003;21:494-495.
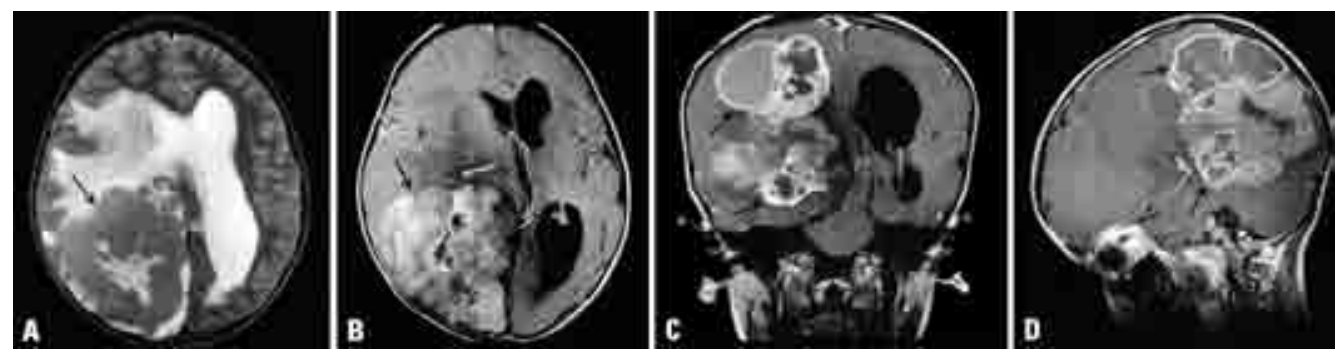

Fig 1. [A] Axial T2 weighted image (WI) demonstrates a right parietooccipital lesion, with low to hyperintensity. Axial [B], coronal [C] and sagittal [D] T1 WI after gadolinium shows a heterogeneously enhancing lesion.

Fig 2. [A] Section through surgical specimen, showing firm, lobulated, whitish gray mass measuring $7 \mathrm{~cm}$ in diameter and weighing $67 \mathrm{~g}$. A fibrotic, partially cystic area is seen at center. Tumor was well delimited from brain, without evidence of invasiveness. [B, C] HE. Moderately cellular, highly fibrillary glial tumor showing round to oval regular nuclei without atypia. The elongated cells were arranged in bundles. Nuclei-free zones were often seen around vessels, but true perivascular pseudorosettes were absent. Mitotic figures or necrotic
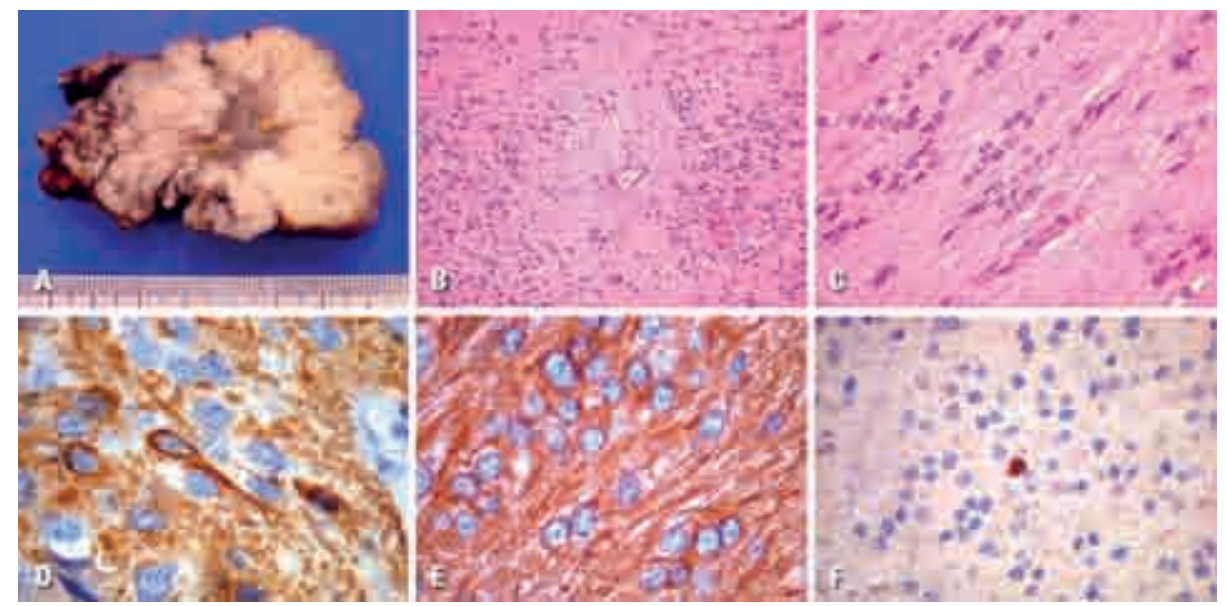
areas were not observed. [D, E] Im-

munohistochemistry for GFAP [D] and vimentin [E]. Tumor cells were strongly positive for both intermediate filaments, sometimes highlighting cell shape. [F] Immunohistochemistry for proliferation marker Ki-67 highlighted only rare scattered nuclei $(<1 \%)$ indicating low growth potential. Tumor cells were negative for epithelial membrane antigen (EMA).

\section{EPENDIMOMA TANICÍTICO SUPRATENTORIAL: UMA VARIANTE FIBRILAR INCOMUM DO EPENDIMOMA}

Faculty of Medical Sciences, Campinas SP, Brazil: ${ }^{1}$ MD, PhD Professor of the Department of Radiology of the Clinics Hospital of the State University of Campinas (UNICAMP), Campinas SP, Brazil; ${ }^{2} \mathrm{MD}$, PhD Professor of the Department of Pathology of the Clinics Hospital, UNICAMP; ${ }^{3} \mathrm{MD}$ Resident of the Department of Radiology of the Clinics Hospital, UNICAMP; ${ }^{4}$ Medicine Student, UNICAMP.

Correspondence: Fabiano Reis - Departamento de Radiologia - Rua Tessália Vieira de Camargo 126 - Cidade Universitária Zeferino Vaz - Caixa Postal: 6111 - $13083-887$ Campinas SP - Brasil. E-mail: fabianoreis2@gmail.com

Support: Fapesp, Introduction to Science' Scholarship.

Received 27 March 2011. Received in final form 13 April 2011. Accepted 20 April 2011. 